\title{
Challenges and Perspectives of Development of Private Pension Funds in Serbia
}

\author{
Marija Đekić $^{1}$ | Miloš Nikolić ${ }^{1}$ | Tamara Vesić ${ }^{1^{*}}$ \\ ${ }^{1}$ Faculty of Business, Economy and Entrepreneurship, Belgrade, Serbia
}

\begin{abstract}
Following the successful implementation of the Chilean reform, the World Bank proposed a solution from three pillars of the pension system: compulsory state, compulsory private and voluntary private pension insurance. Serbia, like many other developed and undeveloped countries, has only adopted the third pillar, in addition to the already existing state. The introduction of compulsory private insurance was also considered. However, there are no market conditions or financial possibilities for achieving this idea. Voluntary pension funds in Serbia were introduced by the 2005 laws. There are seven voluntary pension funds in Serbia, managed by four management companies. So far, the funds have achieved positive yields, although due to limited investment opportunities, these rates were very modest. In addition to limited investment opportunities, one of the problems is the accumulation of funds. The problem of population savings has many sides, and it is certain that some of the causes can be sought in bad experiences from the past. The paper analyses the limitations and possibilities for further development of private pension funds.
\end{abstract}

Key words: voluntary pension insurance, private pension funds, savings, private pensions, security in old age

JEL Classification: G23, J32

\section{INTRODUCTION}

The pension systems of most countries in the world are based on a system of ongoing financing, which is characterised by the fact that employees, through contributions, finance the pensions of those people who have completed their working life. However, this kind of intergenerational solidarity is not sustainable in the long run. The main reasons for this tendency are demographic and financial nature. For the sustainability of such a pension system, demographic factors are not favourable due to the ageing of the population and the increasing share of those over 65 in the total population, from one, and low fertility rates, on the other. The problem of financing pensions in Serbia arose in the 1980s with the occurrence of deficit in the Pension and Disability Insurance Fund. It reached its peak in the 1990s in times of crisis, sanctions and economic decline. The decrease in the number of employees, avoidance to pay employee contributions and a widespread grey economy brought about a decline in the number of policyholders (Pjanic \& Lucic, 2012). As a result, there is greater pressure on the financial side because currently employees are unable to fund pensions without increasing their contributions.

\footnotetext{
${ }^{*}$ Corresponding author, e-mail: tamara.vesic@vspep.edu.rs
} 
The increase in contributions in Serbia is not an appropriate measure because it affects the increase in operating costs, which can further reflect the reduced competitiveness of the company and the economy, as well as the increase in tax evasion. In Serbia, there are tougher measures regarding the non-registration of workers, but this form of grey economy is still at a high level. In the case of a state pension system, workers often try to reduce the excessive burden of pure taxes by adjusting their working lives and work volumes, or by switching to an informal labour market, most commonly in developing countries, where there are ways to avoid pension and other taxes. Companies respond to more labour costs by adopting less labourintensive technology or by switching to informal markets (Corsetti \& Schmidt-Hebbel, 1995). So, the reform of the pay-as-you-go system should not be directed just towards expenditures or to the reduction of insurance rights, but it should also include a better look at income: better control over the payment of contributions for compulsory pensions or disability insurance; an increase in the number of employees; and the reduction in the grey economy; etc. (Kosanovic \& Paunovic, 2010). Since 1981 close to forty countries have introduced systemic pension reforms that have replaced all or part of prior pay-as-you-go (PAYG) schemes with privately managed systems. Since The Great Recession, some European countries that had partly privatised their pension systems between the mid-1990s and early 2000s increasingly scaled back their mandatory private retirement accounts and restored the role of public provision (Wang, Williamson \& Cansoy, 2016; Naczyk \& Domonkos, 2016). In the period after the crisis, because of the increase in unemployment and the reduction of tax revenues, the redirection of contributions to private pension insurance has become too expensive, so some countries have permanently (Hungary, Bulgaria since 2015), and some temporary (Estonia) suspended the second pillar of pension by reducing the contribution rate (Poland, Romania, Latvia, Lithuania, Slovakia) (Horstmann, 2012, p. 11)

The process of globalisation, that is, the process of integration of the world economy has a great influence on the reforms of the pension system. This can be seen in Eastern Europe, where countries that are hoping to join the European Union must reduce their fiscal deficits and limit the overall debt burden (Schiffrin \& Bisat, 2004). These are requirements that involve a reduction in investment in pension insurance and must be undertaken prior to EU accession (Domonkos \& Simonovits, 2016).

With this in mind, it is clear that reforms of the pension system are necessary not only in countries in transition but also in all countries that are facing the problem of financing pensions (Kastratovic, Kalicanin, 2017). „Serbia opted for a more traditional western European approach, combining PAYG cost-containment parametric reforms with the introduction of tax-preferred supplementary private pensions" (Altiparmakov \& Matkovic, 2018). In this regard, the process of starting the reform of the pension system in Serbia has led to the introduction of the third pillar of pension insurance, according to the World Bank classification system. These three pillars The World Bank proposed in its report "Averting the old-age crisis", 1994, proposing the basic concepts and principles of model implementation. After that, her attention was focused on individual solutions adapted to the different conditions and needs of countries with different structure of the population (Tolos, Wang, Zhang \& Shand, 2014). Additionally, although the EU does not elaborate a unitary approach for all member states since about 2000, the Commission has implemented the multi-pillar approach of the World Bank. The approaches of the EU are summarised and systematised in the 2012 White Paper (Windwehr, 2017). Of course, in addition to the fact that the reform allowed the appearance of the first and third pillar of the pension system, periodic changes occurred in the functioning of the pension system, as well as the introduction of new and changing existing one's legal provisions. However, in this paper, the functioning of private pension funds in Serbia is analysed and the obstacles faced by these institutional investors. 


\section{SECTOR FOR VOLUNTARY PENSION FUNDS IN SERBIA}

The past few decades of old-age pension policy have been characterized as an age of privatisation (Ebbinghaus, 2015). In recent decades "pension privatisation," has become one of the most widely implemented reforms (Holzmann, Hinz \& Dorfman, 2008). In the early to mid1990s, many European countries introduced voluntary pension funds. In the period from 1998 to 2006, some countries in Europe introduced a three-tier model of the pension system.

Pension reforms enacted since the 1980s can be grouped into three categories: Parametric reform, Supplemental systemic reform and Extensive systemic reform (Wang, Williamson \& Cansoy, 2016). Pension reform is not cheap, but a good fiscal discipline can make it feasible. The main problem of replacing the PAYGO system with the system of individual pension accounts is high transitional costs. If active contributors contribute to the new system, there remains a financial gap in the old one. The number of contributors then decreases, but the government must continue paying to current pension beneficiaries. These high fiscal costs were evident during the Chilean reform. What's extraordinary in Chile is that although total tax burdens have fallen by about $10 \%$ of GDP, fiscal accounts have remained in surplus for most of the time since the late 1980s. The long-term effects of replacing the system are positive, as shown by all previous estimates, as well as projections of the World Bank that the debt of the pension system without reform in 2050 would amount to $211 \%$ of GDP, and with the implemented reform, the debt should be zero (Vial \& Melguizo, 2009). In Chile, the idea of a private pension system has been developed, where each employee has his individual account in a private fund to which he pays contribution. The Chilean private pension system model emerged as an alternative to the Bismarck idea of the pension system. Most countries in the world that have a pension system have entered the modified application of the idea that originated in Chile (Vukotic, 2004). Several countries of the Western Balkans have introduced partially privatised three-pillar pension systems in an environment of underdeveloped capital markets. It highlights the problems and risks facing the partially privatised pension schemes. The inadequate introduction of individual private-sector pension accounts in many European developing countries stems from high operating costs and unhedged capital markets. These conclusions are based on empirical data for one decade in developing countries that have privatised retirement systems (Altiparmakov, 2011). The Western Balkans' pension system analysis suggests that those countries that have not introduced a three-pillar pension system do not have to do that yet, but focus on improving the efficiency of existing pay-as-you-go systems (Bartlett \& Xhumari, 2007).

The second pillar in the developing countries is characterized by high administrative costs and very low contribution rate, which represent the main reasons for leaving this type of pension system (OECD, 2013, p. 10). Since there is no evidence that the introduction of the second pillar into the domestic pension system creates conditions for a safer and sufficiently high pension, the reforms kept the parametric changes in the first pillar, and in 2006, the first voluntary pension funds emerged as a result of the introduction of the third pillar. However, voluntary pension insurance in Serbia began to develop before the adoption of the Law on Voluntary Pension Funds and Pension Plans, in 2002, when certain forms of savings were similar to today's voluntary pension insurance (Damnjanovic, 2017). The third pillar was designed as a voluntary private pension scheme. However, well known is that pensioners are vulnerable and disadvantaged groups, and in $20147.9 \%$ of the poor in the age group of $46-64$ years, and $7.4 \%$ of the poor in the group of 65 years and more, so it is necessary to take into new reforms to order to improve that facts (Djukic, Balaban \& Radisavljevic, 2017). Many authors (Bartlett \& Xhumari, 2007; Altiparmakov, 2011; Altiparmakov, 2013) agree that, as the reform continues, Serbia should focus on parametric changes of the first pillar and the adequate integration of voluntary pension funds into the pension system of Serbia. 


\section{The current state of the voluntary pension funds sector in Serbia}

Voluntary pension insurance, as a form of pension insurance, is in our country at the beginning of its development and represents an additional form of retirement benefit. At the end of 2017, voluntary pension funds in Serbia operated four management companies that managed the assets of seven voluntary pension funds, one custodian bank and five intermediary banks. Membership in the fund is divided into the accumulation phase - the period when the funds are paid, and the withdrawal phase. In the period from 2008 to the end of 2017, the number of users increased by almost thirty thousand. Of course, the number of contracts is higher, given that one user can conclude more contracts with voluntary pension funds. From year to year, the number of users and contracts increases, but so far positive movement of investment units, FONDex and net assets of funds have been recorded.

Fund assets are the sum of the various investment instruments in which the asset is invested. The net asset value is equal to the difference between the fund assets value and the fund's liabilities on the same day, ie to the result of the multiplication of the number of investment units and the value of the investment unit. The net assets of pension funds at the end of the third quarter of 2017 amounted to 34.9 billion dinars. The change in the value of the assets is influenced by the net payments of funds into funds, payments of funds from funds and the profits made by the funds from the investment (National bank of Serbia, 2017). The nominal net return on investments in pension funds in Serbia for 2016 amounted to $7.4 \%$ and real 5.8\%. In the period after the financial crisis, i.e. for the period from the end of 2011 to the end of 2016, Serbia is among the countries that achieved the highest five-year average real investment rates (without investment costs), that is, Serbia is in second place with 7,1\%, and only the Dominican Republic with 8\% in front of Serbia. This OECD report covered 45 countries (OECD, 2017).

Table 1. Net assets of voluntary pension funds by years.

\begin{tabular}{|l|r|r|r|r|r|r|r|r|r|r|r|}
\hline Year & $\mathbf{2 0 0 7}$ & $\mathbf{2 0 0 8}$ & $\mathbf{2 0 0 9}$ & $\mathbf{2 0 1 0}$ & $\mathbf{2 0 1 1}$ & $\mathbf{2 0 1 2}$ & $\mathbf{2 0 1 3}$ & $\mathbf{2 0 1 4}$ & $\mathbf{2 0 1 5}$ & $\mathbf{2 0 1 6}$ & $\mathbf{2 0 1 7}$ \\
\hline $\begin{array}{l}\text { Net assets } \\
\text { (bill. din.) }\end{array}$ & 3,1 & 4,6 & 7,2 & 9,9 & 12,5 & 16,0 & 19,7 & 23,6 & 28,9 & 32,8 & 34,9 \\
\hline
\end{tabular}

Source: National bank of Serbia, 2017

In Serbia, it is still difficult to determine the stable rate of return of pension funds due to the frequent fluctuation of the value of pension fund units. Funding costs are high, which significantly reduces yields.

\section{Structure of investment of voluntary pension funds in Serbia}

Pension funds in diverse financial markets primarily invest in long-term securities with high yields. Their investment strategies depend on several factors. Due to legal constraints, public funds invest more in low-risk securities, while private pension funds invest in shares, futures and other risk capital to achieve higher yields. Voluntary pension insurance in Serbia differs from the public in that the funds in the personal accounts of the insured are invested and the realised profit is credited quarterly to each account, thus increasing these funds. A favourable tax treatment, which implies the exemption from the tax on all profits, as long as funds held by the fund have resulted in funds being invested in securities for high tax burdens that yield and yield more. Such a favourable tax treatment greatly influenced the growth of size and the importance of these institutional investors.

The differences in the structure of the portfolio of pension funds depend on many factors in addition to the aforementioned tax restrictions, and above all the returns provided by various assets, the risks that carry those assets, but also many regulatory constraints. Investments are 
made to increase the total return but in accordance with the basic principles of investment activities related to portfolio security, portfolio diversification and portfolio liquidity.

The pension funds' portfolio must contain liquid assets of a certain volume so that funds can at any time respond to the due liabilities. Nevertheless, most of the assets of pension funds consist of long-term financial investments in stocks and bonds. The safest and least risky instruments are long-term government bonds, but many funds, for their greater return, nevertheless determine for holding shares in their portfolio.

Bonds in the past have taken a significant place in the structure of the portfolio of pension funds, as these institutional investors are cautious investors. In the US, Japan and Canada, during the 1980 s, bonds accounted for $50 \%$ of the total assets, and in Germany, $30 \%$. However, in the United Kingdom bonds accounted for around $20 \%$ of the total assets of the funds, while most of the portfolios constituted shares. Today, corporative bonds and stocks prevail in the portfolio of pension funds in the world (Labudovic, 2010).

In the countries of Central and Eastern Europe, the share of government bonds in the portfolio is even more pronounced. Due to this structure of the portfolio, there is no significant difference between private pension funds and pension funds in the PAYGO system.

In 2014, pension funds in the OECD countries invested on average $23.8 \%$ of portfolios in shares, $51.3 \%$ in bonds and bonds, and $9.6 \%$ of portfolios were in deposits and cash. Private pension funds at the end of that year had \$ 38 trillion worth of assets in OECD countries (OECD, 2015).

Unlike the developed financial markets, the Serbian stock market, despite notable growth in the volume of transactions, is generally still very illiquid. The small number of companies whose shares are actively traded and an inadequate offer of shares are the main problems for the further development of the market. The liquidity coefficient, as a ratio of total turnover and total market capitalisation, is very low.

The financial market of Serbia imposes a large number of restrictions on institutional investors, and therefore on pension funds. One of these constraints relates to the inability of a good diversification of portfolios, i.e. pension funds are forced to invest in certain market segments. Due to the low liquidity of the market, the prices of securities vary and move very quickly in very high ranges. Also, a major constraint is the lack of low-risk securities, such as corporate or municipal bonds.

In 2007, before entering the financial crisis, there was a tendency to increase investment in shares, a slight decrease in the share of debt securities and an increase in the amount of transaction accounts, as a result of the underdevelopment of the capital market and the weak supply of financial instruments (Matkovic, Bajec, Mijatovic, Zivkovic \& Stanic, 2009).

The largest part of the funds of pension funds in Serbia was invested in bonds $83.7 \%$, the next place in the structure of the assets of the funds was $7.5 \%$, the shares were invested $7.1 \%$ of the assets, in the time deposits $1.1 \%$, and the rest of the funds in the amount of $0.6 \%$, was invested in other securities, real estate, investment units of open investment funds and other forms of receivables. Compared to the previous year, the share of cash and the share of government bonds in the total portfolio structure of all funds decreased, while the share of time deposits and shares increased (National bank of Serbia, 2017).

\section{PERSPECTIVES FOR THE DEVELOPMENT OF THE PRIVATE PENSION FUND SECTOR IN SERBIA}

The performance of the pension system and the development of the voluntary pension funds sector depend on the overall state of the economy of a country. Obstacles for the development of the third pillar are numerous: low incomes, insufficient tax incentives, high rates for compulsory pension insurance, but also mistrust and lack of knowledge of potential beneficiaries (Matkovic, 
2016). The perspectives of pension funds should be viewed in the context of the overall economic reforms, the economic environment and the institutional framework of the country.

The European Bank for Reconstruction and Development (EBRD) announces a set of indicators for the development of the countries in transition, on the basis of which it assesses the process of reforms of these countries from a planned to an open market economy. Transition indicators range from 1 to $4+$, where 1 represents little or no change compared to rigidly planned economies, and 4+ represents the standards of an industrialised market economy.

Table 2. Transition indicators for the financial sector of the countries in the region for 20162017

\begin{tabular}{|c|c|c|c|c|}
\hline \multirow[b]{2}{*}{ Countries in the region } & \multicolumn{4}{|c|}{ Financial sector } \\
\hline & Banking & $\begin{array}{l}\text { Insurance and } \\
\text { fin. services }\end{array}$ & Private Equity & Capital market \\
\hline Bosnia and Herzegovina & $3-$ & $2+$ & 2- & 2 \\
\hline Macedonia & 3- & 3- & 1 & 2 \\
\hline Montenegro & 3- & $2+$ & 1 & 2 \\
\hline Serbia & $3-$ & 3 & 2 & 2 \\
\hline Romania & 3 & $3+$ & 3- & $3-$ \\
\hline
\end{tabular}

Source: EBRD, 2016

The third pillar is a result of citizens' voluntariness if strict legal regulations are created for its functioning with strict control by the state (Birovljev, Vojinovic \& Mirovic, 2015). For the voluntary pension funds to function in the right way, it is necessary to introduce several formal and material conditions, such as in the field of fiscal policy, which would improve tax incentives for contributions to voluntary pension funds.

Certain tax exemptions have been introduced in Serbia since the creation of voluntary pension funds. In addition to being introduced, they have been increased several times. Thus, in February 2009, by amending the Law on Personal Income Tax, the maximum non-taxable payment into voluntary pension funds in Serbia from 3,303 dinars was increased to 3528 dinars (Laketic, 2010). Amendments to the Law on Personal Income Tax, which came into force on $1^{\text {st }}$ of January 2016, this amount was increased to 5501 dinars a month (Law on Income Tax on Income of Citizens). This is not about large amounts, but it can be seen that there is the will and support of the state in the development of the third pillar of the pension system in Serbia. Employers were thus given the opportunity to increase the number of contributions they pay for their employees and that they were exempt from paying citizens' income tax and contributions for compulsory social security.

Table 3.Total investments in pension funds in Serbia in the period from 2010 to 2014.

\begin{tabular}{|l|r|r|}
\hline Year & Investments in millions of dinars & Percent of GDP \\
\hline 2010 & 9912 & 0.3 \\
\hline 2011 & 12493 & 0.4 \\
\hline 2012 & 16366 & 0.5 \\
\hline 2013 & 19747 & 0.5 \\
\hline 2014 & 23654 & 0.6 \\
\hline 2015 & 28954 & 0,7 \\
\hline 2016 & 32860 & 0,8 \\
\hline
\end{tabular}

Source: OECD, 2017

The great potential for further growth in the number of pension funders is in companies with a large number of employees since the largest number of payments to pension funds is precisely the payment of employers' salaries. However, the slower development of private pension funds 
in countries in the region than in developed countries has more causes. First of all, the limiting factor is a poorly developed capital market, which results in limited investment opportunities for these funds. Secondly, the big problem is the poor experience of saving, fraud and fraud related to the financial institutions and the financial system of Serbia. Thirdly, on the EU level, a large number of regulations govern only indirectly operations of these investors. Some of the relevant regulations are MiFID, UCITS, the directive on pension funds (Pension Funds Directive) and directives, which are loosely linked to capital requirements (Capital Requirements Directive). In Serbia, there is still no clear regulations for these investors, although, for years, there are institutions that operate in this region (DJekic, Gavrilovic, Roganovic i Gojkovic, 2017). Fourthly, there is a pronounced low level of cultural investment in Serbia, that is, there is a lack of knowledge of the population and insufficient knowledge of the concept of private pension and the operation of private pension funds. Therefore, in addition to the market, legal, political and institutional frameworks, there is a problem from the aspect of the population, which is very unfavourable for the accumulation of funds. According to (Bilankov \& Aleksic, 2016) "an increased popularisation and education of the citizens would make these voluntary funds leading investors in the market."

\section{EMPIRICAL RESEARCH - METHODOLOGICAL ISSUES}

The aim of the paper is to examine the problems and the perspective of the development of voluntary pension insurance in Serbia. Since private insurance in Serbia is characterized by the principle of voluntarism, since in Serbia there are the first and third pillars of the Pension System according to the World Bank's categorization, it is concluded that the consciousness, opinion and opinion of citizens regarding private pension importance is of great importance for the further development of the pension system. In this regard, the following research questions were asked: How many respondents are familiar with the concept of voluntary pension insurance and private pension funds? How many respondents have confidence in financial institutions in Serbia? How much does the impact on the decision on private pension insurance have a living standard?

To obtain answers to the above research questions, empirical research was carried out using the survey method. The survey was conducted in the period from mid-December 2017 to midJanuary 2018, and the method of a random selection of respondents was applied. The sample of the respondents is a free random sample, consisting of 104 respondents.

Results analysis was performed using IBM SPSS Statistics 21. Depending on the characteristics of the variables and the relationships established between them, some results are shown by cross-tabulation, while some variables show descriptive measures. Also, a hi-square analysis was performed, and data for variables were shown for which there is a proven linkage.

\section{Results of empirical research}

In the conducted research, basic information about the respondents was obtained. The observed characteristics of the subjects can be summarised as follows:

1. In terms of gender, there is no significant difference between the groups, i.e. 51 (or $49 \%$ ) of the male respondents, and the female 53 (or $51 \%$ );

2. Regarding the educational structure, the highest number of respondents with the completed secondary school were 38 (or 36.5\%) and completed basic higher education studies of 33 (or $31.7 \%$ );

3. Regarding the age of the respondents, the majority of respondents belong to age groups of $25-35$ years (29 subjects or $27.9 \%$ ) and $35-45$ years (28 subjects or $26.9 \%$ );

4. In terms of employment, most respondents are employed (89 respondents or $85.6 \%$ ), while a small number of respondents are unemployed (15 respondents or 14.4\%). 
Table 4. Educational structure of respondents

\begin{tabular}{|r|r|r|r|r|}
\hline High School & $\begin{array}{c}\text { college/ } \\
\text { university }\end{array}$ & $\begin{array}{c}\text { faculty-basic } \\
\text { studies }\end{array}$ & $\begin{array}{c}\text { college-master } \\
\text { studies }\end{array}$ & PhD studies \\
\hline $36,6 \%$ & $13,5 \%$ & $31,7 \%$ & $16,3 \%$ & $1,9 \%$ \\
\hline
\end{tabular}

Source: Authors

Table 5. Age structure of respondents

\begin{tabular}{|r|r|r|r|r|}
\hline \multicolumn{1}{|l|}{ up to 25 years } & 25-35 years & 35-45 years & 45-55 years & 55-65 years \\
\hline $3,8 \%$ & $27,9 \%$ & $26,9 \%$ & $20,2 \%$ & $21,2 \%$ \\
\hline
\end{tabular}

Source: Authors

The largest number of respondents in this random sample is not a member of any private pension fund or even $92.3 \%$ of respondents. Through Cross tabulation, we can conclude that respondents, whether they are or not members of the private pension fund, state a low standard of living as the biggest obstacle for higher investment in private pensions.

Table 6. Opinion of the respondents on the biggest obstacles to investing in private pensions in Serbia

\begin{tabular}{|l|r|r|r|r|}
\hline & \multicolumn{1}{|c|}{$\begin{array}{c}\text { Funds are paid } \\
\text { personally }\end{array}$} & \multicolumn{1}{c|}{$\begin{array}{c}\text { Funds are paid by } \\
\text { the employer }\end{array}$} & \multicolumn{1}{c|}{$\begin{array}{c}\text { They are not } \\
\text { members }\end{array}$} & \multicolumn{1}{c|}{$\begin{array}{c}\text { In } \\
\text { total }\end{array}$} \\
\hline low standard of living & 3 & 2 & 62 & 67 \\
\hline$\%$ & $2,9 \%$ & $1,9 \%$ & $59,6 \%$ & $64,4 \%$ \\
\hline $\begin{array}{l}\text { insufficient information on } \\
\text { PP0 }\end{array}$ & 1 & 2 & 13 & 16 \\
\hline$\%$ & $1,0 \%$ & $1,9 \%$ & $12,5 \%$ & $15,4 \%$ \\
\hline $\begin{array}{l}\text { poor trust of citizens in fin. } \\
\text { institutions }\end{array}$ & 0 & 0 & 12 & 12 \\
\hline$\%$ & $0,0 \%$ & $0,0 \%$ & $11,5 \%$ & $11,5 \%$ \\
\hline $\begin{array}{l}\text { disinterested for security } \\
\text { in the future }\end{array}$ & 0 & 0 & 4 & 4 \\
\hline$\%$ & $0,0 \%$ & $0,0 \%$ & $3,8 \%$ & $3,8 \%$ \\
\hline I do not know & $0,0 \%$ & 0 & 5 & 5 \\
\hline$\%$ & 4 & 4 & $4,8 \%$ & $4,8 \%$ \\
\hline In total & $3,8 \%$ & $3,8 \%$ & 96 & 104 \\
\hline$\%$ & & & $92,3 \%$ & $100,0 \%$ \\
\hline
\end{tabular}

Source: Authors

The table below shows descriptive measures for the four questions asked by respondents. On all questions, the respondents gave answers on the Lickert scale from one to five. However, on the first two questions, the answers are graded, so that the grades of 1-absolutely agree, to 5absolutely disagree; and on the other two issues I'm completely aware of the 1st, I'm not familiar with 5 . Based on the data, the following can be concluded:

1. Respondents have different trusts in financial institutions, but the average attitude is neutral, that is, neither trust nor trust in financial institutions;

2. The respondents highly believe that a better standard is needed for citizens' interest, as is shown by the fact that no respondent replied that he disagrees with this claim, as well as the mean value and the standard deviation that indicates that there is no high deviation in answers); 
3. The respondents are better acquainted with the presence and operation of private pension funds than with the concept of private pension insurance, but generally speaking, they are not familiar with each other or are partially acquainted.

Table 7. Descriptive statistics for individual variables

\begin{tabular}{|l|r|r|r|r|}
\hline Variables & \multicolumn{1}{|l|}{ Min } & \multicolumn{1}{|l|}{ Max } & \multicolumn{1}{l|}{ Mean } & St. Dev. \\
\hline 1. I have trust in financial institutions in the Republic of Serbia & 1 & 5 & 3,06 & 1,022 \\
\hline $\begin{array}{l}\text { 2. Is it necessary for a better standard of citizens' interest in } \\
\text { investing in paid pensions }\end{array}$ & 1 & 4 & 1,68 &, 728 \\
\hline 3. Are you familiar with the concept of private pension insurance & 1 & 5 & 2,78 & 1,024 \\
\hline $\begin{array}{l}\text { 4. Are you familiar with the presence and business of private } \\
\text { pension funds in Serbia }\end{array}$ & 1 & 5 & 2,91 & 1,098 \\
\hline
\end{tabular}

Source: Authors

Also, it is important to note that $76.9 \%$ of respondents want additional income because they believe that state pensions are not enough for a secure age, and $4.8 \%$ of respondents consider that state pensions are not enough for security in old age, but that they do not want additional income. Only $18.3 \%$ of respondents believe that state pensions are sufficient for a secure age, of which $15.4 \%$ still want additional income, while the other $2.9 \%$ do not want.

The next graph shows the opinion of the respondents regarding the biggest advantages of investing in private pension funds. It can be concluded that as many as $39.4 \%$ of the respondents consider that the greatest advantage of investing in private pensions is that the amount of private pension does not depend on years of service, but on the total payments and how these funds are invested.

Table 8: The biggest advantages of investing in private pension funds according to respondents' opinion

\begin{tabular}{|l|r|}
\hline Advantages & Percentage \\
\hline tax exemptions can be made to the contributions paid into the fund & $4,8 \%$ \\
\hline $\begin{array}{l}\text { private pension does not depend on the length of service, but from the total payments } \\
\text { and income of the fund }\end{array}$ & $39,4 \%$ \\
\hline they do not have to make regular payments but can be paused in monthly payments & $16,3 \%$ \\
\hline they do not have to make regular payments but can be paused in monthly payments & $11,5 \%$ \\
\hline they do not have to make regular payments but can be paused in monthly payments & $11,5 \%$ \\
\hline none of the above & $16,3 \%$ \\
\hline
\end{tabular}

Source: Authors

Below are the data obtained by testing the variability of variables using the hi-square test. Only those links that we found statistically significant are shown in the body. Based on the realized values of the hi-square statistics, the significance level of the test (As. Sig.) And the observation of the obtained coefficients (Cramer's V and the Contingency Coefficient), we have come to the conclusion that there is dependence between the following variables: Level of education and familiarity with the concept of private pension insurance; Level of education and familiarity with the presence and operation of private pension funds in Serbia; Knowledge of the concept of private pension insurance and familiarity with the presence and operation of private pension funds in Serbia. 
Table 9: Results of the conducted empirical analysis using the hi-square test

\begin{tabular}{|c|c|c|c|c|c|c|c|c|}
\hline \multicolumn{2}{|c|}{ Variable } & \multicolumn{2}{|c|}{ Pearson Chi-Square } & \multirow{2}{*}{ df } & \multicolumn{2}{|c|}{ Cramer's V } & \multicolumn{2}{|c|}{ Contingency Coeff. } \\
\hline First & The other one & Val. & As.Sig. & & Val. & Ap.Sig. & Val. & Ap.Sig. \\
\hline $\begin{array}{l}\text { Level of } \\
\text { education }\end{array}$ & $\begin{array}{l}\text { Familiarity with the } \\
\text { concept of PPO }\end{array}$ & 17,339 & 0,027 & 8 & 0,289 & 0,027 & 0,378 & 0,027 \\
\hline $\begin{array}{l}\text { Level of } \\
\text { education }\end{array}$ & $\begin{array}{l}\text { Awareness of the } \\
\text { presence and } \\
\text { business of PPF in } \\
\text { Serbia }\end{array}$ & 15,607 & 0,048 & 8 & 0,274 & 0,048 & 0,361 & 0,048 \\
\hline $\begin{array}{l}\text { Familiarity } \\
\text { with the } \\
\text { concept of } \\
\text { PPO }\end{array}$ & $\begin{array}{l}\text { Awareness of the } \\
\text { presence and } \\
\text { business of PPF in } \\
\text { Serbia }\end{array}$ & 91,041 & 0,000 & 4 & 0,662 & 0,000 & 0,683 & 0,000 \\
\hline
\end{tabular}

Source: Authors

It can be concluded that respondents with a higher level of education are more familiar with the concept of private pension insurance and with the presence and operation of private pension funds in Serbia. This relationship is statistically significant but not strong.

We also conclude that those respondents who are familiar with the concept of private pension insurance are also familiar with the presence and operation of private pension funds in Serbia. Previous connections are logical, but the last connection is very strong and statistically significant. Connections among other variables were also investigated, but no statistical data were obtained.

\section{CONCLUSION}

The pension system in Serbia, as well as the systems of a large number of countries in the world, faces the problem of functioning and the crisis in financing. In the last few years, pension spending in Serbia is $13 \%$ of the GDP, which is $4.5 \%$ more than the average found in European countries in transition and it is a burden that Serbian economy and taxpayers cannot bear in the long run (Veselinovic, 2014). The most common reasons for the difficulty of financing state pension funds are demographic nature. Due to the poor sustainability of state funds, many countries have gone through or are still going through the reform processes of the pension system. Apart from the parametric reform of the state system of current financing, the reform of the pension system in Serbia included the introduction of voluntary pension insurance. Pension reforms in Serbia have long since begun, but it cannot yet be considered that this process has been completed. During several reforms in Serbia, the pension system has undergone certain changes that relate to parametric reforms in the first pillar of the pension system (according to the World Bank classification system) and the introduction of the third pillar. The introduction of the second pillar is not a good solution, which is also supported by the experiences of other developing countries. Further recommendations to ensure the better functioning of the pension system relate to the increase of the efficiency of the first pillar, but also the promotion of the development of voluntary pension funds in Serbia. Private pension funds (third pillar) exist in Serbia for more than a decade, but their development is limited by market, legal, institutional and political factors. Also, some of the restrictions also relate to the population of Serbia, as can be seen from the conducted research. By analysing the answers to the set research questions, we conclude the following:

1. The knowledge of the respondents with the concept of voluntary pension insurance and private pension funds is not at a satisfactory level, and is related to the level of education of the respondents;

2. The level of confidence of respondents in financial institutions in Serbia is not satisfactory, as on average respondents have a neutral attitude on this issue; 
3. The largest number of respondents cite the standard of living as the biggest obstacle for higher private pension investments, and most agree that for citizens to invest in private pension funds, it is necessary to improve the standard of citizens in Serbia.

In future research, features and variables varied on a sample consisting of respondents who are members of private pension insurance should be examined in order to gain a better insight into the average profile of a person who decides to become a member of a private pension fund and to examine the features and link attributes with this type of sample.

\section{REFERENCES}

Altiparmakov, N. (2011). "A macro-financial analysis of pension system reforms in emerging Europe: The performance of IRAs and policy lessons for Serbia." International Social Security Review, 64 (2): 23-44.

Altiparmakov, N. (2013). "Is there an alternative to the pay-as-you-go pension system in Serbia?" Economic Annals, 58 (198): 89-114.

Altiparmakov, N. \& Matkovic, G. (2018). "The development of private pensions in Serbia: caught between a generic blueprint and an unconducive local environment." Transfer: European Review of Labour and Research, 24 (1): 57-71.

Bartlett, W. \& Xhumari, M. (2007). "Social security policy and pension reforms in the Western Balkans." European Journal of Social Security, 9 (4): 297-321.

Bilankov, B. \& Aleksic, D. (2016). "Voluntary pension insurance as a method of solving the pension system crisis." Pravo i privreda, 54, (7-9): 669-694.

Birovljev, J., Vojinovic, Z. \& Mirovic, V. (2015). "Funkcionalna zavisnost kategorija korisnika penzija u odnosu na ukupan broj zaposlenih." Ekonomske teme, 53 (3): 361-383.

Corsetti, G. \& Schmidt - Hebbel, K. (1995). "Pension Reform and Growth." Policy Research Working Paper No. 1471. The World Bank (Policy Research Department).

Damnjanovic, R. (2017). "Dobrovoljno penzijsko osiguranje kao mogucnost dodatne finansijske sigurnosti." Vojno delo, 69 (2): 322-332.

Domonkos, S. \& Simonovits, A. (2016). "Pensions in transition in EU11 countries between 1990 and 2015." Downloaded on 14th of January 2018 from http://econ.core.hu /file/download/mtdp/MTDP1615.pdf

Djekic, M., Gavrilovic, M., Roganovic, M. \& Gojkovic, R. (2017). "The Role of Investment Funds in Countries with Transition Economies." Economic Analysis, 50 (1-2): 1-12.

Djukic, G., Balaban, M. \& Radisavljevic, G. (2017). The Macroeconomic Framework of the Functioning of Public Compulsory Pension Insurance. Economic Analysis, 50 (1-2): 26-37.

Ebbinghaus, B. (2015). "The privatization and marketization of pensions in Europe: A double transformation facing the crisis." European Policy Analysis, 1(1): 56-73.

EBRD. 2016. Transition Report 2016-2017. Downloaded on 15th of January 2018 from https://www.ebrd.com/transition-report

Holzmann, R., Hinz, R.P. \& Dorfman, M. (2008). "Pension systems and reform conceptual framework (Social protection discussion paper, No. 824)." Washington: World Bank.

Horstmann, S. (2012). "Synthesis Report 2012: Pensions, health care and long-term care." Downloaded on 15th of January 2018 from http://socialprotection.eu/

Kastratovic, E., Kalicanin, M. \& Kalicanin, Z. (2017). "Features of Cash Flow Compared to Profit". Internatonal Review, 3-4: 50-57.

Kosanovic, R. \& Paunovic, S. (2010). "The reform of the pensions system in Serbia and the proposals of the International Monetary Fund." Journal for Labour and Social Affairs in Eastern Europe, 13 (1): 103-120.

Labudovic, J. (2010). "Plasmani sredstava dobrovoljnih penzijskih fondova. Evropske reforme u pravu osiguranja Srbije," Beograd: Udruzenje za pravo osiguranja Srbije, 265-282.

Laketic, D. (2010). "Penzioni fondovi i ekonomski razvoj".Kriza i razvoj. Beograd: Centar za ekonomska istrazivanja Instituta drustvenih nauka: 431-437. 
Matkovic, G. (2016). "Mirovinski sustav Srbije u svjetlu krize." Revija za socijalnu politiku, 23 (1): 99-119.

Matkovic, G., Bajec, J., Mijatovic, B., Zivkovic, B. \& Stanic, K. (2009). Izazovi uvodjenja obaveznog privatnog penzijskog sistema u Srbiji. Beograd: Centar za liberalno-demokratske studije.

Naczyk, M. \& Domonkos, S. (2016). "The financial crisis and varieties of pension privatization reversals in Eastern Europe." Governance, 29 (2): 167-184.

National bank of Serbia. 2017. Sektor dobrovoljnih penzijskih fondova - izvestaj za trece tromesecje 2017. godine. Downloaded on 8th of January 2018 from http://www.nbs.rs/internet/latinica/62/62_2/dpf_03_17.pdf

OECD. 2013. Pensions at a Glance 2013: OECD and G20 Indicators. Downloaded on 18th of January 2018 from sa sajta http://www.oecd.org/pensions/public-pensions/OECD PensionsAtAGlance2013.pdf

OECD. 2015. Pension Markets in Focus. Downloaded on 11th of January 2018 from http://www.oecd.org/pensions/private-pensions/Pension-Markets-in-Focus-2017.pdf

OECD. 2017. Pension Markets in Focus. Preuzeto 13.aprila 2018. sa sajta http://www.oecd.org/daf/fin/private-pensions/Pension-Markets-in-Focus-2017.pdf

Pjanic, M. \& Lucic, D. (2012). "Reforma penzijskog sistema Srbije u uslovima ekonomskofinansijske krize." Anali ekonomskog fakulteta u Subotici, 48 (28): 109-122.

Schiffrin, A. \& Bisat, A. (2004). "Covering Globalization." New York: Columbia University Press.

Tolos, H., Wang, P., Zhang, M. \& Shand, R. (2014). "Retirement systems and pension reform: A Malaysian perspective." International Labour Review, 153: 489-502.

Veselinovic, P. (2014). "Reforma javnog sektora kao kljucna determinanta uspesnosti tranzicije privrede Republike Srbije." Ekonomski horizonti, 16 (2): 141-159.

Vial, J. \& Melguizo, A. (2009). "Moving from pay-as-you-go to privately managed individual pension accounts: What have we learned after 25 years of the Chilean pension reform?" Pensions, 14: 14-27.

Vukotic, V. (2004). "Penzijske reforme kao novi potencijal ekonomskog rasta." Podgorica: Institut za strateske studije i prognoze.

Wang, X., Williamson, J. \& Cansoy, M. (2016). "Developing countries and systemic pension reforms: Reflections on some emerging problems." International Social Security Review, 69 (2): 85-106.

Windwehr, J. (2017). "Europeanization in Pension Policy: the Crisis as a Game-Changer?" Journal of Contemporary European Research 13 (3): 1301-1318.

Law on Income Tax on Income of Citizens, "Sluzbeni glasnik", br. 112/2015.

Article history: $\quad$ Received: November 13, 2018

Accepted: May 31, 2019 